\title{
Procesy deindustrializacji i reindustrializacji przestrzeni miejskich na przykładzie Lublina
}

Processes of deindustrialization and reindustrialization of urban spaces:

The Lublin example

\section{Wprowadzenie}

Postępująca w drugiej połowie XX w. globalizacja, porzucenie fordowskiego modelu produkcji przemysłowej i nowe ujęcie międzynarodowego podziału pracy przyczyniły się do deindustrializacji światowych gospodarek (Błaszczyk, 2015, S. 5). Proces ten rozpatrywać można jako naturalną konsekwencję postępu gospodarczego w krajach rozwiniętych, skutkującą m.in. długookresowym spadkiem udziału zatrudnionych w przemyśle przy jednoczesnym wzroście udziału zatrudnienia w sektorze usług. W teorii bowiem sektor usług powinien absorbować uwolnione z branży produkcyjnej zasoby ludzkie, jednak w warunkach jego niewystarczającego poziomu produktywności (determinowanego m.in. rozwojem technologicznym) pojawiają się negatywne skutki deindustrializacji, w tym problem bezrobocia czy obniżających się standardów życia mieszkańców, a także kryzys ośrodków miejskich, postępująca depopulacja i problem zagospodarowania terenów poprzemysłowych (Śliwa \& Waląg, 2017, s. 124).

Postfordowski paradygmat rozwoju w kontekście zachodzących globalnie przemian społeczno-gospodarczych zakładał rozwój miast, których gospodarki napędzane są wiedzą, innowacjami, kulturą, turystyką i rozwojem branży finansowej, ubezpieczeniowej czy rynku nieruchomości. Uciążliwa zarówno dla środowiska, jak i ludności produkcja przemysłowa miała zostać przeniesiona do krajów rozwijających się, pozostawiając w krajach rozwiniętych jedynie centra zarządcze i badawczo-rozwojowe. Okazało się jednak, że działania te nie budują 
ekonomicznych podstaw do dalszego, trwałego rozwoju (Błaszczyk, 2015, s. 9-10). Polityka outsourcingowania działalności przemysłowej skutkuje bowiem spadkiem zdolności generowania zaawansowanych technologicznie produktów, co znacznie obniża poziom konkurencyjności gospodarek (Pisano \& Shih, 2009, s. 114-125). Stąd pojawiła się konieczność restytucji działalności przemysłowej, do której nawiązują dwa skojarzone ze sobą procesy: reindustrializacja i neoindustrializacja. Reindustrializacja to nie tylko klasyczne odtwarzanie funkcji przemysłu w gospodarce i dążenie do zwiększenia jego udziału w tworzeniu PKB. To przede wszystkim zmiana struktury gałęziowo-branżowej, wzrost znaczenia przemysłów nowoczesnych w ramach tzw. gospodarki opartej na wiedzy, przy jednoczesnym odejściu od tradycyjnych przemysłów surowcowych. W myśl tej koncepcji przewaga konkurencyjna lokalnych gospodarek ma być budowana dzięki przemysłom elastycznym, o produkcji nisko- lub średnioskalowej, $\mathrm{z}$ dostępem do odpowiedniego otoczenia biznesu, uwzględniającego usługi finansowe czy zaplecze technologiczne (Błaszczyk, 2015, s. 13). Według teorii neoindustrializacji głównym czynnikiem napędzającym wzrost gospodarczy są zasoby wiedzy i umiejętności. Związane jest to z rozwojem tych branż, w których prym wiedzie tzw. „kapitał kreatywny”, akumulowany w oparciu o działalność objętą ochroną wartości intelektualnej. W tym ujęciu proces uprzemysłowienia jest ściśle związany z rewolucją cyfrową (Błaszczyk, 2015, s. 12).

Istotnym aspektem reindustrializacji oraz neoindustrializacji jest fakt wprowadzania przemysłu do już istniejącego ładu lokalnego - przemysł przestaje być czynnikiem miastotwórczym w znaczeniu nadanym mu podczas pierwszej rewolucji przemysłowej. Nowa industrializacja adaptuje się do struktur istniejących w miastach, uzupełniając ich funkcje konsumpcyjne i mieszkalne. Odtworzenie bazy produkcyjnej służy aktywizacji i włączeniu istniejących w mieście zasobów społecznych, przestrzennych, kulturowych itp., co sprawia, że wzrost ma charakter endogenny i nie jest już uzależniony jedynie od czynników zewnętrznych (Błaszczyk, 2015, s. 14).

Obserwowany obecnie proces dynamicznych, globalnych przemian technologicznych i organizacyjnych, powodujący spadek udziału przemysłu w tworzeniu PKB i w zatrudnieniu w większości krajów europejskich, nie zmienia faktu, że sektor przemysłu, będący producentem dóbr inwestycyjnych dla wszystkich pozostałych działów gospodarki, wciąż ma decydujący wpływ na wzrost stopy życiowej większości społeczeństw współczesnego świata. Działalność prowadzona przez przedsiębiorstwa produkcyjne to jeden z kluczowych czynników rozwoju regionalnego. Wzrost efektywności i konkurencyjności firm przemysłowych ma 
bezpośredni wpływ na rozwój całego regionu - przemysł jest bowiem fundamentem rozwoju technicznego i technologicznego oraz nośnikiem innowacyjności.

Polska była jednym z tych krajów, które w wyniku przemian ustrojowo-gospodarczych po 1989 r. w największym stopniu zostały dotknięte negatywnymi skutkami deindustrializacji. Katastrofa przemysłowa, której doświadczyła, skutkowała likwidacją 40\% zakładów przemysłowych, zatrudniających niemal 840 tys. osób (Karpiński, Paradysz, Soroka \& Żółtkowski, 2013, s. 210). Polskie miasta, posiadające $w$ większości charakter przemysłowy, traciły swe funkcje - w efekcie regresu bazy ekonomicznej dochodziło do niekorzystnych zmian demograficznych. W Łodzi proces depopulacji po upadku przemysłu włókienniczego skutkował 20\% spadkiem liczby ludności (do 2015 r.), którego nie rekompensował wzrost liczby mieszkańców w strefie podmiejskiej (Krzysztofik \& Szmytkie, 2018, s. 316). W grupie miast średniej wielkości jednym z najbardziej poszkodowanych w wyniku silnych procesów deindustrializacyjnych okazał się Lublin - miasto posiadające wieloletnią tradycję przemysłową, dotknięte zostało upadkiem sześciu spośród 16 zakładów produkcyjnych (Karpiński i in., 2013, s. 211), w efekcie czego zatrudnienie w przemyśle zmniejszyło się o 75\% (w porównaniu do 1988 r.). W końcu, po latach intensywnej deindustrializacji i światowych kryzysach finansowych, w Polsce następuje proces odbudowy pozycji konkurencyjnej przemysłu nie tylko pod kątem ilościowym, ale przede wszystkim jakościowym, uwzględniającym wzrost znaczenia zaawansowanych technologii w procesach produkcyjnych.

Celem artykułu jest przedstawienie zmian, jakim podlegał przemysł w Lublinie po 1989 r. w obliczu zachodzących w kraju przemian ustrojowych i społeczno-ekonomicznych, a także rozwoju technologicznego przedsiębiorstw produkcyjnych. Zwrócono również uwagę na rolę prowadzonej polityki gospodarczej zarówno szczebla lokalnego, jak i krajowego oraz ponadnarodowego - we wzmacnianiu konkurencyjności podmiotów gospodarczych, prowadzących działalność w branżach przemysłowych, a tym samym konkurencyjności miast i regionów. Wykorzystana w artykule metoda studium przypadku pozwoliła na przeprowadzenie szczegółowej analizy złożonych procesów deindustrializacji i reindustrializacji miasta, determinujących jego pozycję konkurencyjną w Polsce i na świecie. 


\section{Gospodarcze konsekwencje transformacji ustrojowej dla miasta Lublina}

Polityczno-ustrojowe i społeczno-gospodarcze przemiany, jakie nastąpiły na przełomie lat 8o. i 9o. XX wieku, wywarły znaczący wpływ na rozwój gospodarczy Lublina i województwa lubelskiego. Ekonomiczna efektywność podmiotów gospodarczych została zweryfikowana podczas procesów transformacji centralnie planowanej gospodarki socjalistycznej w gospodarkę rynkową. Pierwsze lata transformacji zarówno w Lublinie, jak i w innych regionach kraju przyniosły liberalizację i konieczność zmierzenia się z negatywnymi skutkami restrukturyzacji dużych podmiotów gospodarczych, które w wyniku zmian ustrojowych utraciły dotychczasowe rynki zbytu i nie były przystosowane do warunków gospodarki rynkowej (Sagan, 2018b, s. 105-107).

W czasach PRL w województwie lubelskim powstało około 80 zakładów przemysłowych, zatrudniających pod koniec lat 80. ponad 89 tys. osób (Karpiński i in., 2013, s. 208-212). Należały do nich m.in.: powstała w 1951 r. Fabryka Samochodów Ciężarowych (zatrudniająca w 1988 r. ponad 7,5 tys. osób), utworzone w 1986 r. Zakłady Metalurgiczne - Odlewnia (z zatrudnieniem w 1988 r. na poziomie 3,2 tys. osób) czy założone jeszcze w 1960 r. Przedsiębiorstwo Jajczarsko-Drobiarskie (dające w 1988 r. pracę niemal 1,2 tys. osób). Firmy zlokalizowane na terenie Lublina skupiały niemal $18 \%$ pracowników, a ich produkcja sprzedana stanowiła 1/4 produkcji sprzedanej całego województwa.

Przemiany ustrojowe przyniosły ograniczenia produkcji, dążenie do minimalizacji obciążeń i kosztów, a tym samym redukcję liczebności załóg pracowniczych. Mimo że wielu przedsiębiorstwom udało się pomyślnie przeprowadzić restrukturyzację i prywatyzację, a nawet zaistnieć na rynkach zagranicznych, to jednak przemiany te doprowadziły do upadku po 1989 r. 30 zakładów produkcyjnych w województwie, w tym 6 w Lublinie, w wyniku czego pracę straciło niemal 12,5 tys. osób w mieście i 41,4 tys. osób w regionie (patrz tabela 1).

Z analizy struktury branżowej przedsiębiorstw powstałych przed 1989 r., które w wyniku przemian politycznych zostały zlikwidowane, wynika, że największe zwolnienia dotknęly pracowników zatrudnionych w tych samych branżach, które przed przemianami dawały najwięcej etatów. Najbardziej poszkodowanym okazał się Lublin, w którym liczba osób zatrudnionych w przemyśle zmniejszyła się w porównaniu do 1988 r. aż $075 \%$.

Jak już podkreślono, jeszcze na początku lat 90. Lublin był znany z dobrze rozwiniętego przemysłu, w którym zatrudniano ponad 41,5 tys. osób spośród 158285 pracujących ogółem (Cienkiera \& Żyśko, 2017, s. 16). Dwa największe 
Tabela 1: Produkcja sprzedana, zatrudnienie oraz wartość brutto środków trwałych zakładów przemysłowych powstałych w latach 1945-1988 (w tym zlikwidowanych po 1989 r.) w Lublinie, województwie lubelskim i w Polsce (stan na koniec 1988 r.)

\begin{tabular}{|l|r|r|r|r|}
\hline \multicolumn{1}{|c|}{ Wyszczególnienie } & $\begin{array}{r}\text { Liczba } \\
\text { zakładów }\end{array}$ & $\begin{array}{c}\text { Produkcja } \\
\text { sprzedana } \\
\text { (w mln zl) }\end{array}$ & $\begin{array}{c}\text { Zatrudnienie } \\
\text { (w osobach) }\end{array}$ & $\begin{array}{c}\text { Wartość brutto } \\
\text { środków trwałych } \\
\text { (w mln zl) }\end{array}$ \\
\hline Zakłady przemysłowe w Lublinie & 16 & 160259 & 16002 & 125748 \\
\hline w tym zlikwidowane po 1989 $r$. & 6 & 114948 & 12471 & 103148 \\
\hline $\begin{array}{l}\text { Zakłady przemysłowe w woj. } \\
\text { lubelskim }\end{array}$ & 83 & 641034 & 89007 & 514237 \\
\hline w tym zlikwidowane po 1989 $r$. & 30 & 273581 & 41400 & 167427 \\
\hline Zakłady przemysłowe w Polsce & 1620 & 16157166 & 1873352 & 12285289 \\
\hline w tym zlikwidowane po 1989 $r$. & 657 & 5825843 & 838307 & 3716414 \\
\hline
\end{tabular}

(Źródło: Opracowanie własne na podstawie: Karpiński i in., 2013, s. 211).

zakłady przemysłowe (Fabryka Samochodów Ciężarowych i Odlewnia Żeliwa) zatrudniały wówczas niemal 11 tys. pracowników, co stanowiło ponad $26 \%$ pracowników przemysłowych i blisko 7\% ogółu pracujących w mieście'. Wskutek procesów związanych $\mathrm{z}$ transformacją zatrudnienie $\mathrm{w}$ Lublinie zmniejszyło się z ponad 158 tysięcy osób w 1990 r. do prawie 115 tysięcy w roku 1993 (patrz wykres 1), czyli o 30\%, co spowodowało konieczność realizacji działań osłonowych, pozostających domeną głównie władz centralnych. Masowe zwolnienia pracowników z dużych zakładów produkcyjnych, w których koncentrowała się produkcja przemysłowa, pociągnęły za sobą szereg zmian demograficznych miasto przestało być atrakcyjnym celem migracji, a młodzi ludzie po ukończeniu nauki wyjeżdżali z Lublina, poszukując pracy w stolicy bądź za granicą.

Przemiany transformacyjne i związane z nimi masowe zwolnienia przyczyniły się do wzrostu bezrobocia w mieście. $\mathrm{O}$ ile zwalniani przedstawiciele kadry kierowniczej, menedżerowie czy inżynierowie zakładali własne działalności gospodarcze lub znajdowali zatrudnienie w firmach prywatnych, o tyle w trudnej sytuacji znaleźli się ludzie o niskich kwalifikacjach zawodowych, którzy w następnych latach szukali pracy w handlu lub usługach. Poprawę sytuacji na rynku pracy przyniosły dopiero lata 1994-1997. Spadek liczby osób bezrobotnych był przede wszystkim wynikiem wysokiego tempa rozwoju gospodarczego w kraju, zmian legislacyjnych w kwestii prawa pracy i zahamowania procesów restrukturyzacyjnych (Cienkiera \& Żyśko, 2017, s. 17). Liczba pracujących w Lublinie w 1997 r. wyniosła prawie 124 tysiące osób i była najwyższa od 1991 roku (wykres 1).

1 Opracowanie własne na podstawie: Karpiński i in., 2013, s. 211. 
Wykres 1: Liczba pracujących ogółem w Lublinie w latach 1990-1999

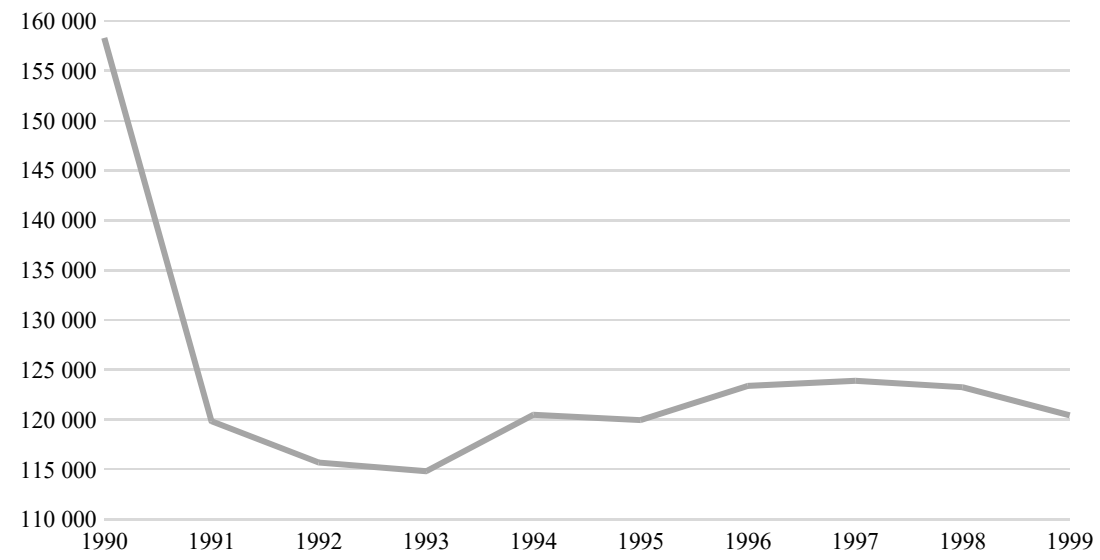

(Źródło: GUS, 2019).

Relatywnie korzystne tendencje w rozwoju sektora przemysłu w Lublinie w drugiej połowie lat 9o. były pochodną przede wszystkim post-transformacyjnego procesu rozwoju małej i średniej przedsiębiorczości oraz korzystnej koniunktury gospodarczej. W sposób szczególny rozkwitał handel, co miało znaczenie dla akumulacji kapitału wśród osób, które planowały inwestycje w przyszłości. Część z nich bowiem zarobione środki relokowała w bardziej zaawansowane formy gospodarowania, np. tworząc niewielkie firmy produkcyjne (Sagan, 2018b, s. 106). Ten boom postaw przedsiębiorczych w mieście zaowocował powstaniem wielu firm, które później odniosły ogromny sukces rynkowy, nierzadko stając się liderami w swoich branżach. W 1999 r. liczba podmiotów gospodarczych zarejestrowanych w rejestrze REGON w Lublinie wyniosła 35070 i była o $27 \%$ wyższa niż w roku 1994 (GUS, 2019).

Wraz ze wzrostem ogólnej liczby przedsiębiorstw rosła liczba firm prowadzących działalność gospodarczą w górnictwie (sekcja D), przetwórstwie przemysłowym (sekcja C) oraz związanych z wytwarzaniem i zaopatrywaniem w energię elektryczną, gaz, wodę (sekcja E). W 1995 r. firmy te stanowiły ponad 9\% ogółu firm zarejestrowanych w Lublinie. Do 1999 r. ich liczba wzrosła o ponad $17 \%$ do prawie 3 tysięcy (GUS, 2019). W grupie przedsiębiorstw przemysłowych (sekcja C, D i E łącznie) największy odsetek w 1995 r. (aż 99\%) stanowiły podmioty prowadzące działalność związaną z przetwórstwem przemysłowym. 


\section{Procesy reindustrializacji gospodarki Lublina po 2000 roku}

Sytuację gospodarczą Lublina i regionu na początku XXI w. ukształtowały dwa zjawiska: niepełna transformacja społeczno-gospodarcza miasta w pierwszej połowie lat 90. XX w. oraz opóźniona o ponad 10 lat post-transformacyjna deindustrializacja z lat 1999-2002. Później globalny kryzys finansowy i gospodarczy w 2008 roku przyniósł wprawdzie kolejne załamanie koniunktury, lecz zarazem przyspieszył tempo przemian strukturalnych w gospodarce światowej, związanych $\mathrm{z}$ internacjonalizacją gospodarki i rewolucją w zakresie technik informacyjnych (Kotyński, 2016, s. 7). Po tych dwóch fazach spadkowych cyklu koniunkturalnego Lublin w końcu zaczął odnotowywać sukcesy. Przyczyn poprawy sytuacji społeczno-gospodarczej szukać można w zmianach w prowadzonej polityce rozwoju na poziomie regionalnym i lokalnym, a także w przemianach technologicznych i innowacyjności. Od kilku lat (zwłaszcza od roku 2016) sektor przemysłu w Lublinie, dla którego początek lat 90. XX wieku, jak też przełom XX i XXI w. był okresem gwałtownej deindustrializacji, znów rośnie.

\subsection{Wzrost poziomu inwestycji i wskaźników przedsiębiorczości}

Osłabienie aktywności gospodarczej w pierwszej dekadzie XXI w. w Lublinie było silniejsze niż w Polsce - w 2004 r. (ale i w całej tej dekadzie, za wyjątkiem roku 2007 i 2010) produkcja sprzedana przemysłu w Lublinie stanowiła jedynie $1 / 2$ średniej krajowej. Na początku XXI w. można było zaobserwować także załamanie inwestycji przedsiębiorstw, których wartość spadła do poziomu $75 \%$ średniej krajowej (Sagan, 2018b, s. 110-112).

Rozwój sektora przemysłu na początku drugiej dekady XXI w., jako rezultat m.in. utworzenia Podstrefy Lublin Specjalnej Strefy Ekonomicznej EURO-PARK Mielec, znalazł odzwierciedlenie w poprawie wskaźników gospodarczych. Fundamentalnym miernikiem działalności przedsiębiorstw przemysłowych jest wartość produkcji sprzedanej - o ile w 2004 r. produkcja sprzedana przemysłu per capita w Lublinie stanowiła 53\% średniej krajowej, to w 2015 r. była już 0 5\% od niej wyższa, a w 2017 r. wyniosła 34396 zł, czyli o 240 zł więcej niż wartość dla Polski (wykres 2). Z kolei w rekordowym 2015 roku nakłady inwestycyjne przedsiębiorstw w Lublinie przekroczyły wartość $4800 \mathrm{zl}$ per capita i stanowily 111\% średniej krajowej (patrz wykres 3) (Sagan, 2018b, s. 111-112, 124; GUS, 2019). 
Wykres 2: Produkcja sprzedana przemysłu na 1 mieszkańca w Lublinie i w Polsce w latach 2002-2017 (w zł)

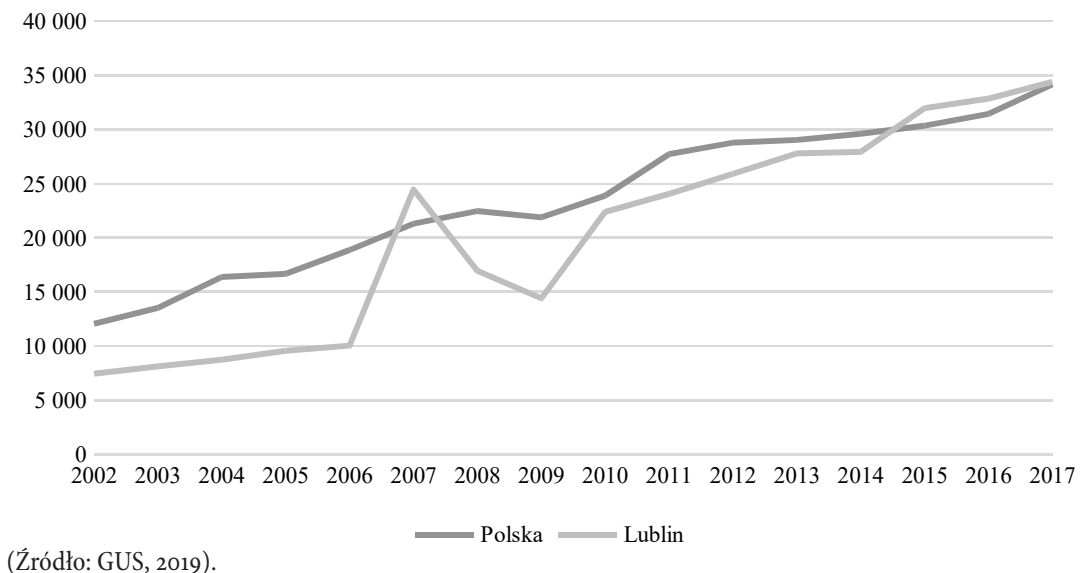

Wykres 3: Nakłady inwestycyjne w przedsiębiorstwach na 1 mieszkańca w Lublinie i w Polsce w latach 2002-2017 (w zł)

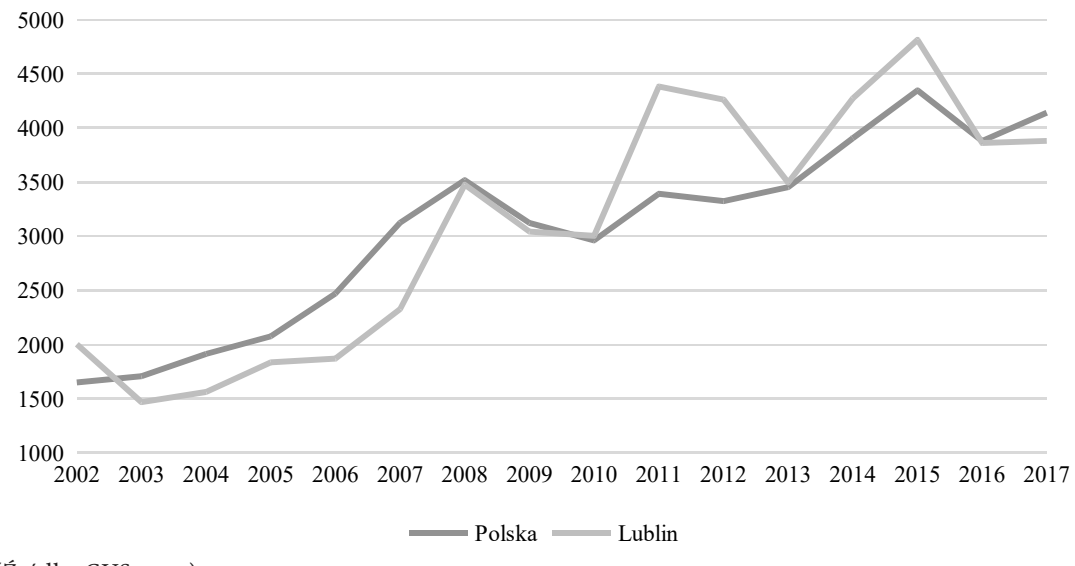

(Źródło: GUS, 2019).

W latach 2002-2010 w Lublinie wskaźniki nasycenia przedsiębiorczością były znacznie niższe niż w innych dużych polskich aglomeracjach. Liczba podmiotów gospodarczych zarejestrowanych w rejestrze REGON w przeliczeniu na 10 tys. mieszkańców oscylowała w granicach 1100 (Sagan, 2018b, s. 112; GUS, 2019). Po $2010 \mathrm{r}$. proces powstawania nowych przedsiębiorstw znacząco przyspieszył, co znalazło odzwierciedlenie w poprawiających się wskaźnikach makroekonomicznych. W 2018 r. liczba przedsiębiorstw w Lublinie wyniosła ponad 45,3 tys. i była 
wyższa o 15,3\% w porównaniu do 2002 roku, zaś wskaźnik przedsiębiorczości osiągnął poziom 1335 (na 10 tys. mieszkańców) (GUS, 2019).

Kluczową dla zmian strukturalnych w gospodarce Lublina i regionu jest zaobserwowana w latach 2012-2016 zdecydowana poprawa w zakresie osiąganych przez lubelskie przedsiębiorstwa przemysłowe przychodów z całokształtu działalności w sekcji C (czyli przetwórstwo przemysłowe dostarczające największej wartości dodanej gospodarce). Wzrosły one, w czym udział mają także lubelskie firmy działające w SSE, do poziomu 8,2 miliarda w 2016 roku, czyli prawie $0100 \%$ w porównaniu do 2010 roku (tabela 2). Jednocześnie zatrudnienie w tych przedsiębiorstwach w analogicznym okresie wzrosło o około $12 \%$, co nawet przy 15\% wzroście poziomu wynagrodzeń oznaczało bardzo wysoki wzrost produktywności lubelskiego przetwórstwa przemysłowego. Niewątpliwie ma to związek $\mathrm{z}$ automatyzacją produkcji oraz oddawaniem do użytkowania nowoczesnych zakładów produkcyjnych, zaprojektowanych tak, aby minimalizować nadmierny wzrost zatrudnienia (Sagan, 2017b, s. 43).

Wzrost przychodów w analizowanym sektorze spowodował geograficzną reorientację znaczenia Lublina w przemysłowym ekosystemie Polski Wschodniej. $\mathrm{O}$ ile w $2010 \mathrm{r}$. wiodącym ośrodkiem w tym względzie (przychody firm z sekcji C przetwórstwo przemysłowe) był Mielec, zaś Lublin zajmował drugą pozycję, to w 2016 r. pozycję zdecydowanego przemysłowego lidera Polski Wschodniej przejął Lublin (przychody lubelskich przedsiębiorstw przemysłowych były wyższe o 32\% niż mieleckich) (Sagan, 2017b, s. 44).

Tabela 2: Przychody przedsiębiorstw w Lublinie w latach 2010-2016 (w tys. zł)

\begin{tabular}{|c|c|c|c|c|c|c|c|}
\hline Wyszczególnienie & 2010 & 2011 & 2012 & 2013 & 2014 & 2015 & 2016 \\
\hline $\begin{array}{l}\text { Łączne przychody } \\
\text { przedsiębiorstw }\end{array}$ & 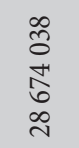 & $\begin{array}{l}\qquad 0 \\
\infty \\
\infty \\
\infty \\
m \\
m\end{array}$ & 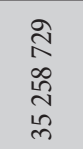 & 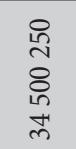 & $\begin{array}{l}\text { F } \\
\infty \\
\infty \\
\infty \\
\stackrel{+}{d}\end{array}$ & $\begin{array}{l}\infty \\
\vec{N} \\
i \\
\infty \\
\infty \\
0 \\
\infty\end{array}$ & 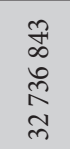 \\
\hline $\begin{array}{l}\text { Przychody przedsiębiorstw } \\
\text { przemysłowych (sekcje B, } \\
\text { C, D, E) }\end{array}$ & \begin{tabular}{l}
$\hat{\sigma}$ \\
\multirow{\delta}{*}{} \\
â
\end{tabular} & $\begin{array}{l}\infty \\
\infty \\
\infty \\
\infty \\
\infty \\
\stackrel{+}{1} \\
\stackrel{1}{\sim}\end{array}$ & 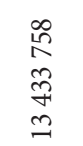 & 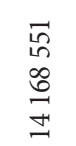 & $\begin{array}{l}\hat{0} \\
\infty \\
2 \\
0 \\
m \\
=\end{array}$ & $\begin{array}{l}\hat{o} \\
\text { L } \\
\text { Lิ } \\
\text { in } \\
\end{array}$ & 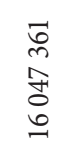 \\
\hline $\begin{array}{l}\text { Przychody przedsiębiorstw } \\
\text { sekcji C wg PKD } 2007\end{array}$ & 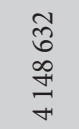 & \begin{tabular}{l} 
N \\
Iิ \\
\multirow{3}{0}{}
\end{tabular} & $\begin{array}{l}\text { oे } \\
\infty \\
\text { ऽิ } \\
\infty \\
0\end{array}$ & $\begin{array}{l}\exists \\
\text { ป } \\
\text { N } \\
\text { N }\end{array}$ & $\begin{array}{l}\frac{2}{1} \\
\frac{1}{5} \\
6\end{array}$ & $\begin{array}{l}\Re \\
\stackrel{2}{\infty} \\
\infty \\
\infty\end{array}$ & $\begin{array}{l}\stackrel{a}{7} \\
\underset{7}{0} \\
\stackrel{1}{N}\end{array}$ \\
\hline
\end{tabular}

(Źródło: Opracowanie własne na podstawie danych Głównego Urzędu Statystycznego [GUS, 2019]). 


\subsection{Poprawa sytuacji na rynku pracy}

Koniec XX w. przyniósł pogorszenie sytuacji na rynku pracy - wzrost bezrobocia po 1998 r. był wynikiem spowolnienia gospodarczego i wygasania zawartych w umowach prywatyzacyjnych zobowiązań, na mocy których firmy musiały utrzymać zatrudnienie na określonym poziomie. Gdy okres umowny minął, w przedsiębiorstwach nastąpiły masowe redukcje. Sytuację w regionie potęgował dodatkowo zły stan zakładów przemysłowych. W 2001 r. spółka Daewoo Motor Poland ogłosiła upadłość, przez co pracę straciło ponad 3 tys. osób. Pod wpływem zwolnień bezrobocie osiągnęło rekordowy poziom - w Lublinie w $2002 \mathrm{r}$. wyniosło 13,7\% przy ponad 20 tysiącach zarejestrowanych osób bez pracy (wykres 4).

Przystąpienie Polski do Unii Europejskiej poprawiło nieco sytuację na lubelskim rynku pracy - mieszkańcy miasta zyskali możliwość podjęcia zatrudnienia w innych krajach członkowskich i pojawiło się tzw. zjawisko „eksportu bezrobocia”; w konsekwencji konkurencja na lokalnym rynku pracy zmniejszyła się. Dodatkowo w wyniku akcesji Polski do UE dla lubelskich firm otworzyły się nowe rynki zbytu. Bezrobocie zaczęło stopniowo maleć - w 2008 r. w Lublinie stopa bezrobocia wyniosła 7,4\%, zbliżając się do poziomu z 1998 r. (Cienkiera \& Żyśko, 2017, s. 18). Stan ten nie trwał jednak długo - krach na rynkach finansowych W 2008 roku przyniósł znaczące pogorszenie sytuacji i do 2013 r. bezrobocie w Lublinie, jak też w całym kraju systematycznie wzrastało.

Wykres 4: Liczba zarejestrowanych osób bezrobotnych w Lublinie w latach 2000-2018

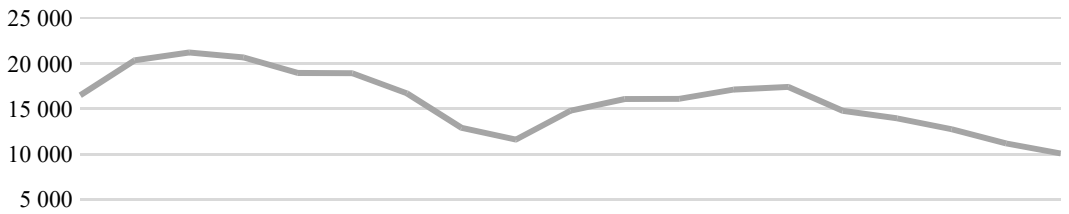

2001200220022003200420052006200720082009201020112012201320142015201620172018 (Źródło: GUS, 2019).

W kolejnych latach sytuacja w Lublinie ulegała systematycznej poprawie, co wiązało się m.in. ze wzrostem liczby miejsc pracy tworzonych przez firmy z sektora przemysłu, które zdecydowały się na inwestycję na terenie Podstrefy Lublin Specjalnej Strefy Ekonomicznej EURO-PARK Mielec. W 2018 r. liczba pracujących w przemyśle w Lublinie wyniosła ponad 18,5 tys. osób i w porównaniu do 2012 r. wzrosła o prawie $20 \%$. W latach 2015-2018 nastąpiły także pierwsze od kilku lat istotne przyrosty zatrudnienia w przetwórstwie przemysłowym w mieście do ponad 15 tys. osób (patrz wykres 5). 
Wykres 5: Pracujący w przemyśle i w przetwórstwie przemysłowym w Lublinie w latach 2005-2018

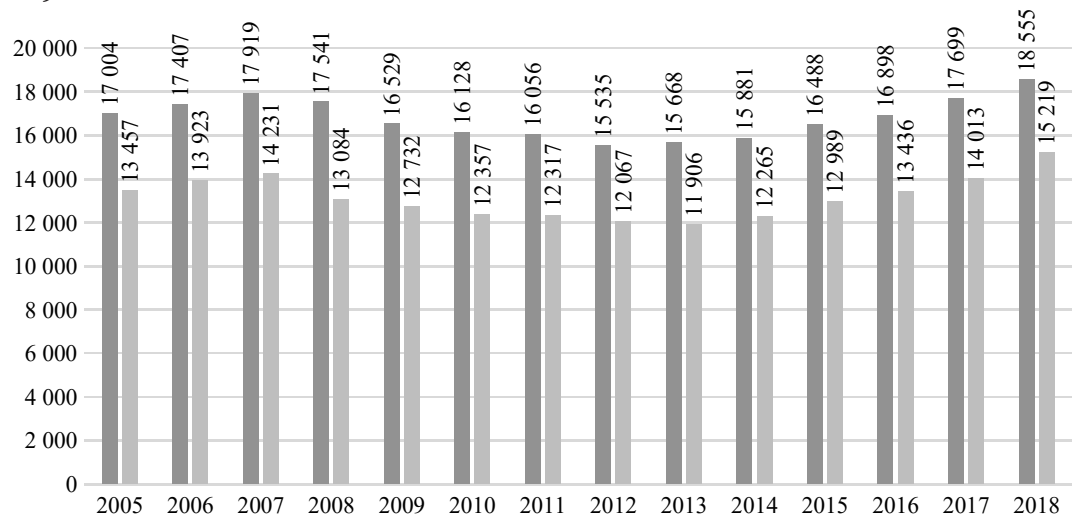

(Źródło: GUS, 2019).

- przemysł $\square$ przetwórstwo przemysłowe

Szybkie przyrosty zatrudnienia w firmach lubelskich, w tym także tych znajdujących się w Specjalnej Strefie Ekonomicznej, znalazły odzwierciedlenie w liczbie pracujących ogółem w Lublinie na koniec 2018 r., która wyniosła 126 tys. osób (GUS, 2019). Tym samym sytuacja pod względem zatrudnienia w mieście na koniec 2018 r. była najlepsza od 1991 r., choć wciąż nie osiągnęła poziomu z 1990 r. Ponadto stopa bezrobocia rejestrowanego we wrześniu 2019 r. w Lublinie wyniosła 4,9\% i była najniższą odnotowaną stopą bezrobocia od początku lat 90. XX wieku.

Wykres 6: Przeciętne miesięczne wynagrodzenie brutto w przemyśle w Lublinie w latach 1990-2018 (w zł)

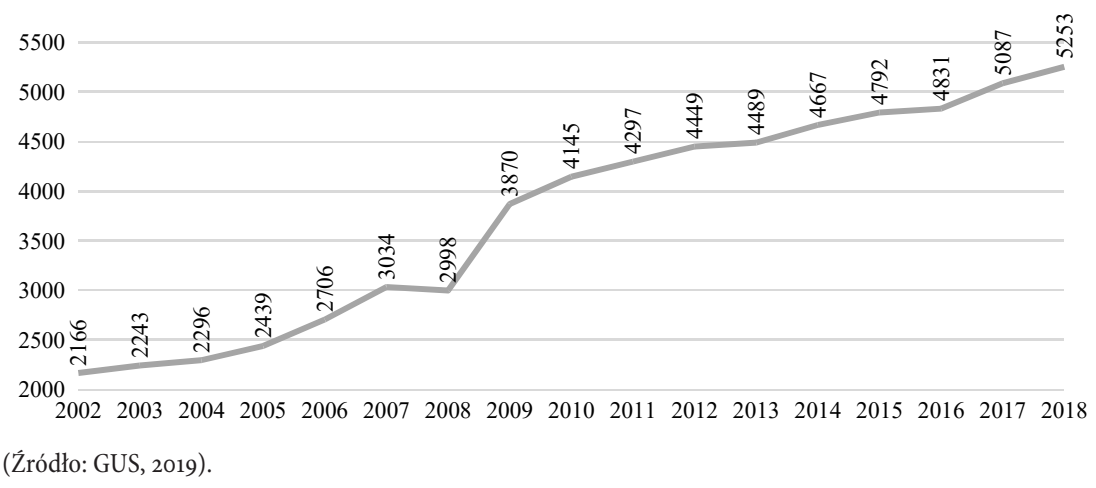


Wraz ze spadkiem bezrobocia oraz poprawą sytuacji gospodarczej w mieście rosły wynagrodzenia. W ciągu ostatnich 17 lat (od $2002 \mathrm{r}$.) przeciętne miesięczne wynagrodzenie brutto ogółem w Lublinie wzrosło ponad dwukrotnie do poziomu 44708 złotych (GUS, 2019). W tym samym czasie poziom przeciętnego miesięcznego wynagrodzenia brutto w przemyśle w mieście wzrósł o 143\% i na koniec 2018 r. wyniósł 5253 zł.

\subsection{Podstrefa Lublin Specjalnej Strefy Ekonomicznej jako kluczowe narzędzie reindustrializacji gospodarki miasta}

Specjalne strefy ekonomiczne to jedno z podstawowych narzędzi polityki gospodarczej i jeden z kluczowych instrumentów rozwoju regionalnego, z powodzeniem stosowany na całym świecie. Proces powstawania stref ekonomicznych w Polsce rozpoczął się w 1995 r. Ponad 20 lat ich funkcjonowania przyniosło dziesiątki tysięcy nowych miejsc pracy w przemyśle i z sukcesem przyczyniło się do reindustrializacji kraju. Potencjał gospodarczy wybranych regionów i miast, przeżywających problemy społeczno-gospodarcze okresu transformacji, został praktycznie odbudowany, a strefy stały się magnesem dla inwestycji zagranicznych, lokowanych głównie w przemyśle, umożliwiając m.in. włączenie naszego kraju w globalne łańcuchy kreowania wartości największych korporacji międzynarodowych. SSE stały się także istotnym elementem wsparcia dla rodzimego biznesu, umożliwiając, dzięki systemowi zwolnień podatkowych oraz dostępności uzbrojonych terenów inwestycyjnych, głównie typu greenfield, efektywne inwestycje i reinwestycje (Sagan, 2017a, s. 9-11).

Przełomowym momentem w odbudowie lubelskiego przemysłu było utworzenie we wrześniu 2007 r. Podstrefy Lublin Specjalnej Strefy Ekonomicznej EURO-PARK Mielec - jednej z pierwszych podstref w województwie lubelskim. Projekt jej utworzenia, zrealizowany stosunkowo późno w porównaniu do innych podstref w kraju, miał na celu przede wszystkim ożywienie gospodarcze i przełamanie negatywnego procesu deindustrializacji miasta, a przy tym podniesienie jego pozycji konkurencyjnej w stosunku do innych miast w Polsce Wschodniej, tworzenie nowych miejsc pracy, a także wprowadzenie impulsu innowacyjnego dla lokalnej gospodarki (Sagan, 2017b, s. 29).

W momencie utworzenia Podstrefa Lublin obejmowała 70 ha nieuzbrojonych terenów o charakterze greenfield, zlokalizowanych we wschodniej części miasta, w dzielnicy Felin. Taka lokalizacja Podstrefy Lublin nie była przypadkowa. Grunty należące do SSE znajdują się w południowo-wschodniej części miasta, w pobliżu 
obwodnicy Lublina, węzła komunikacyjnego trasy ekspresowej S-17 oraz Portu Lotniczego Lublin S.A. (Gruba, Niewiadomski \& Olchowska, 2017, s. 77). Obecnie, po trzech rozszerzeniach, których dokonano w 2009 r. (10 ha), 2010 r. (36 ha) oraz 2015 r. (12 ha), powierzchnia lubelskiej podstrefy obejmuje teren 128 ha w trzech częściach Lublina (na Felinie, na Wrotkowie oraz na terenie byłej Fabryki Samochodów Ciężarowych) i jest niemal w całości zagospodarowana.

Pierwsze pięć lat działalności Podstrefy Lublin, obejmujące okres do połowy 2013 r., było procesem powolnego wzrostu liczby udzielonych zezwoleń i funkcjonujących inwestorów. Przyczyny tej sytuacji szukać należy przede wszystkim w braku uzbrojonych gruntów miejskich, które mogłyby być oferowane w konkurencyjnych cenach inwestorom; rolę odegrało również spowolnienie gospodarki światowej po kryzysie w 2008 r. Rocznie wydawano dwa, trzy pozwolenia na działalność strefową, przy czym wyjątek stanowił 2009 r., kiedy do podstrefy włączono dziewięć przedsiębiorstw, które jeszcze przed 2007 r. deklarowały chęć wejścia i zmaterializowały swoje plany inwestycyjne. W okresie tego rozruchu, w czerwcu 2013 r., w strefie funkcjonowało 20 firm, w tym 10 prowadzących działalność produkcyjną.

Zdecydowanie korzystniejszym okresem dla funkcjonowania lubelskiej podstrefy były lata 2013-2018, do czego przyczyniły się takie kwestie, jak realizacja projektów infrastrukturalnych dotyczących uzbrojenia działek czy oparta o najlepsze wzorce promocja oferty inwestycyjnej Lublina w Polsce i zagranicą, prowadzona przez Urząd Miasta Lublin. Uzbrojenie terenów strefowych, obejmujące m.in. budowę sieci dróg wewnętrznych oraz infrastruktury sieciowej (wodociągi, kanalizacja), w dużej mierze zrealizowano dzięki RPO Województwa Lubelskiego w ramach projektu pod nazwą „Infrastruktura dla strefy ekonomicznej na Felinie w Lublinie", opiewającego w pierwszym jego etapie na kwotę blisko $26 \mathrm{mln}$ zł.

Rocznie od 5 do 7 firm uzyskiwało zezwolenie na prowadzenie działalności w lubelskiej podstrefie. Dodatkowo, po pozyskaniu do strefy dwóch globalnych operatorów produkcyjno-magazynowych, w SSE zaczęły inwestować podmioty z branży logistycznej i produkcyjnej. W 2016 r. oddano ponadto do użytkowania pierwsze dedykowane sektorowi usług powierzchnie biurowe, co spowodowało napływ do Podstrefy Lublin nowych najemców z branży IT, dywersyfikując tym samym strukturę biznesu w strefie.

Na koniec czerwca 2019 r. w Podstrefie Lublin obecnych było 70 inwestorów, dysponujących 36 zezwoleniami strefowymi (patrz wykres 7 ). 0 ile w początkowych kilku latach funkcjonowania podstrefa miała charakter przemysłowy, o tyle po 2012 r. w efekcie dołączenia do oferty powierzchni magazynowej i biurowej, 
Wykres 7: Zezwolenia oraz inwestorzy na terenie Podstrefy Lublin w latach 2008-2019

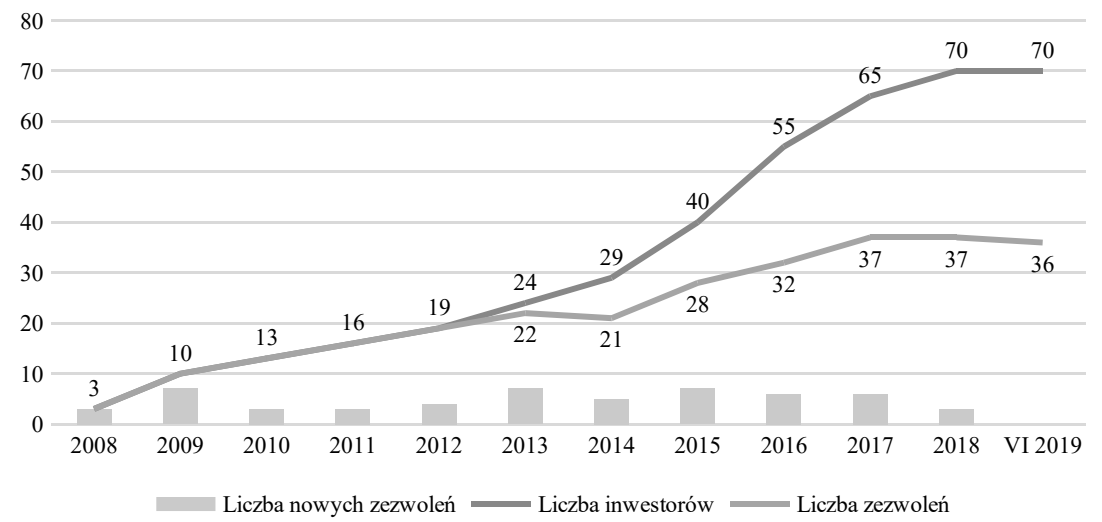

(Źródło: Urząd Miasta Lublin, 2019).

liczba przedsiębiorstw z branży usługowej i logistycznej wyniosła 33, według stanu na koniec czerwca 2019.

Jak wspomniano wcześniej, jednym z podstawowych celów utworzenia Podstrefy Lublin było tworzenie nowych miejsc pracy przy jednoczesnym utrzymaniu dotychczasowych, co zwłaszcza w pierwszym etapie funkcjonowania strefy okazało się nie lada wyzwaniem. Wzrost liczby nowych miejsc pracy skorelowany był przede wszystkim z nowymi inwestorami sukcesywnie otwierającymi kolejne fabryki na terenie lubelskiej podstrefy. Dynamiczny wzrost zatrudnienia nastąpił po 2014 roku. Na koniec czerwca 2019 r. na całym obszarze Podstrefy

Wykres 8: Zatrudnienie na terenie Podstrefy Lublin w latach 2008-2019

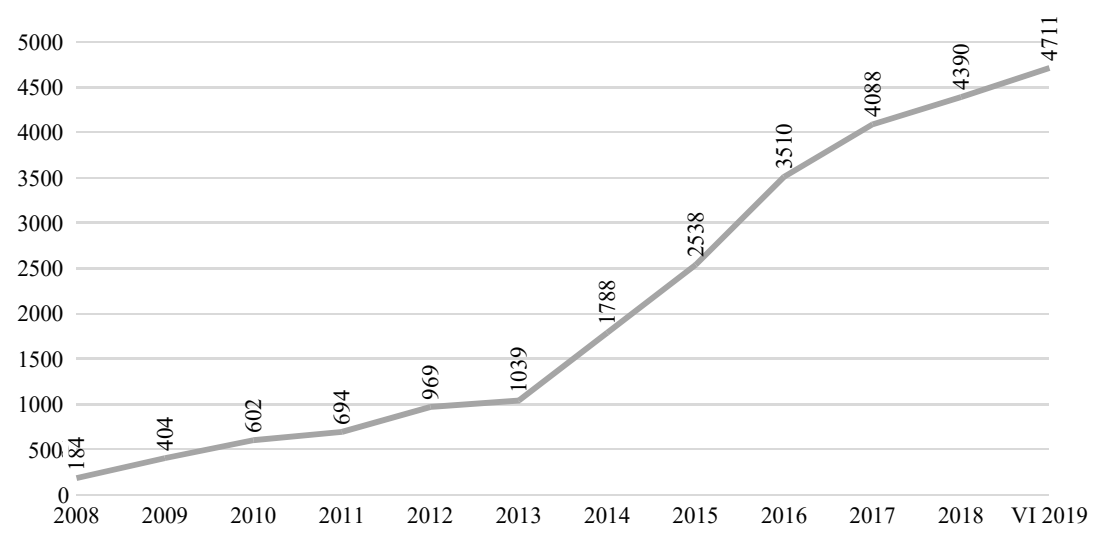

(Źródło: Urząd Miasta Lublin, 2019). 
Lublin pracowało ponad 4,7 tys. osób, z czego ponad 3,6 tys. to nowoutworzone miejsca pracy (patrz wykres 8 i tabela 3 ).

Firmy, które w latach 2008-2019 uzyskały pozwolenie właściwego ministra na prowadzenie działalności w Podstrefie Lublin zadeklarowały utworzenie ponad 2,1 tys. miejsc pracy. Realnie w ciągu 10 lat funkcjonowania podstrefy powstało ich ponad 1,4 tys. więcej.

Tabela 3: Zatrudnienie na terenie Podstrefy Lublin w latach 2008-2019

\begin{tabular}{|l|r|r|r|r|r|r|r|r|r|r|r|r|}
\cline { 2 - 12 } \multicolumn{1}{|l|}{ Wyszczególnienie } & $\mathbf{2 0 0 8}$ & $\mathbf{2 0 0 9}$ & $\mathbf{2 0 1 0}$ & $\mathbf{2 0 1 1}$ & $\mathbf{2 0 1 2}$ & $\mathbf{2 0 1 3}$ & $\mathbf{2 0 1 4}$ & $\mathbf{2 0 1 5}$ & $\mathbf{2 0 1 6}$ & $\mathbf{2 0 1 7}$ & $\mathbf{2 0 1 8}$ & $\begin{array}{c}\text { VI } \\
\mathbf{2 0 1 9}\end{array}$ \\
\hline $\begin{array}{l}\text { Deklarowane } \\
\text { miejsca pracy }\end{array}$ & 390 & 662 & $\mathbf{7 7 5}$ & 833 & 841 & 985 & 1095 & 1240 & 1523 & 1609 & 2169 & 2161 \\
\hline $\begin{array}{l}\text { Utworzone nowe } \\
\text { miejsca pracy }\end{array}$ & 184 & 223 & 199 & 304 & 567 & 588 & 1048 & 1449 & 2293 & 2940 & 3221 & 3605 \\
\hline $\begin{array}{l}\text { Utrzymane } \\
\text { miejsca pracy }\end{array}$ & 0 & 181 & 403 & 390 & 402 & 451 & 740 & 1089 & 1217 & 1148 & 1169 & 1106 \\
\hline $\begin{array}{l}\text { Lączna liczba } \\
\text { miejsc pracy }\end{array}$ & 184 & 404 & 602 & 694 & 969 & 1039 & 1788 & 2538 & 3510 & 4088 & 4390 & 4711 \\
\hline
\end{tabular}

(Źródło: Urząd Miasta Lublin, 2019).

Mimo rosnącej liczby przedsiębiorstw z sektora usług i logistyki na terenie Podstrefy Lublin, w zatrudnieniu wciąż dominują osoby pracujące w firmach przemysłowych. Na koniec czerwca 2019 r. stanowiły 84\% ogółu zatrudnionych w lubelskiej podstrefie, a ich liczba w ciągu 10 lat wzrosła ponad dwudziestokrotnie (wykres 9).

Wykres 9: Łączna liczba miejsc pracy na terenie Podstrefy Lublin w podziale na przemysł, usługi i logistykę w latach 2008-2019

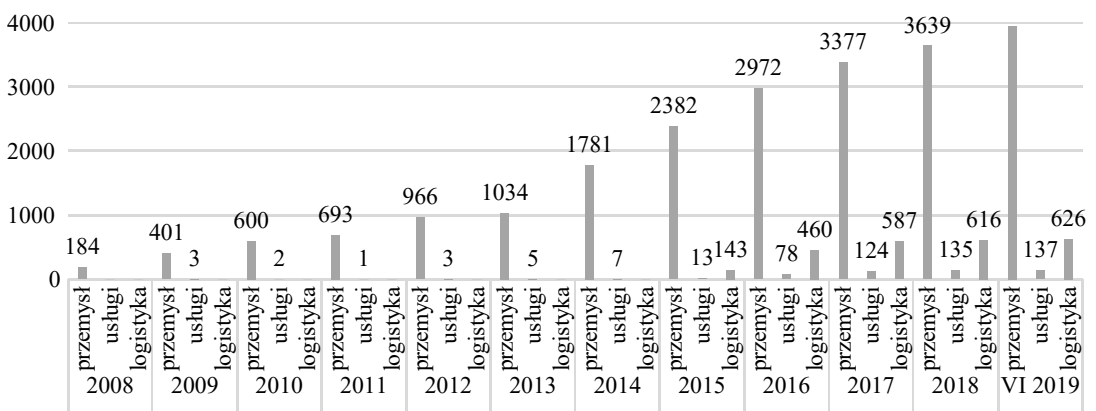

(Źródło: Urząd Miasta Lublin, 2019). 
Wykres 10: Wartość zrealizowanych nakładów inwestycyjnych na terenie Podstrefy Lublin w podziale na przemysł i usługi w latach 2008-2019

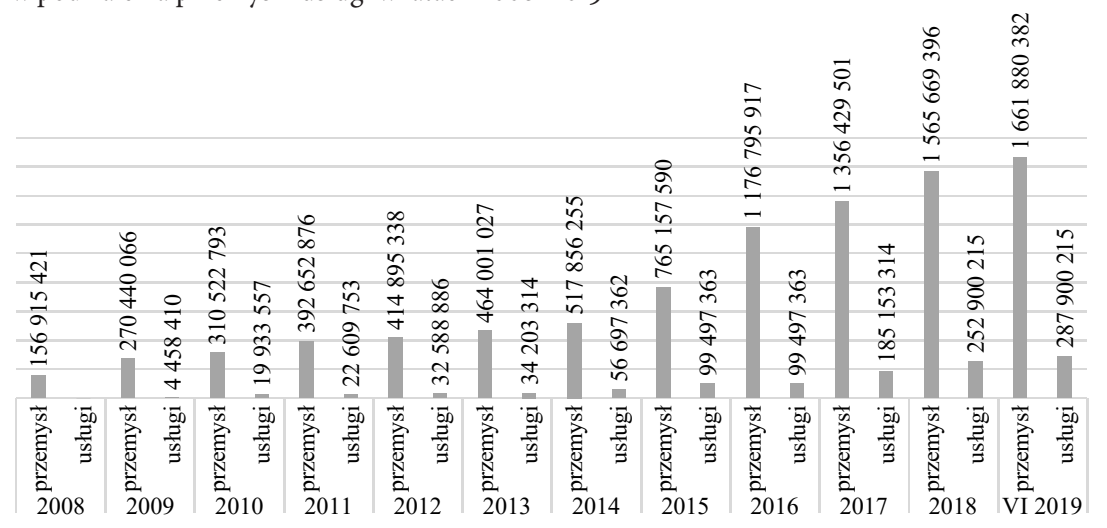

(Źródło: Urząd Miasta Lubli n, 2019).

W latach 2008-2019 podmioty obecne w lubelskiej podstrefie poniosły znaczące nakłady inwestycyjne. Łącznie przez 12 lat firmy przemysłowe zainwestowały w Podstrefie Lublin niemal 2 mld zł. Co więcej, od 2016 r. relacja zrealizowanych nakładów inwestycyjnych w stosunku do nakładów deklarowanych w SSE wynosi ponad $130 \%$ (wykres 11).

Wykres 11: Realizacja nakładów inwestycyjnych na terenie Podstrefy Lublin w latach 2008-2019 (w \%)

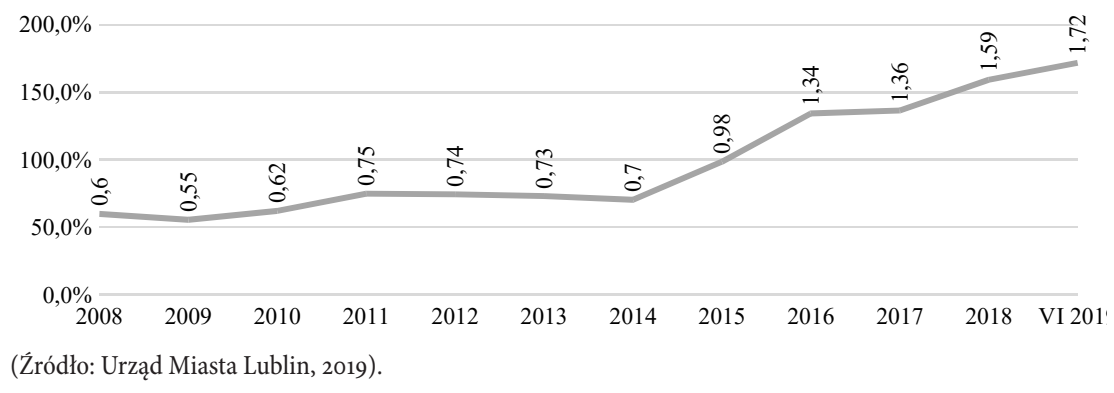




\section{Podsumowanie}

Na rozwój zarówno Lublina, jak i całego województwa lubelskiego, silny wpływ miały uwarunkowania geopolityczne czy kwestie związane z dostępnością komunikacyjną. Dokonująca się na początku lat 90. XX w. transformacja społeczno-ekonomiczna Polski zweryfikowała efektywność funkcjonowania zakładów przemysłowych. Po okresie intensywnej deindustrializacji, upadku dużych firm przemysłowych i przemianach restrukturyzacyjnych na przełomie XX i XXI wieku, lata 2015-2019 przyniosły niespotykaną dotąd dynamikę gospodarczego rozwoju miasta. Część firm z branż zaawansowanych technologicznie przeszła udaną restrukturyzację, a w tradycyjnych sektorach przemysłowych powstały nowe podmioty gospodarcze. Sytuacja w przemyśle zaczęła się stabilizować, a obecnie można zaobserwować coraz szybszy rozwój tego sektora w Lublinie (Sagan, 2014, s. 180).

Obecna dekada bez wątpienia może zostać uznana za przełomową. Z perspektywy 2005 r., kiedy stworzono pierwszą w okresie transformacyjnym strategię rozwoju miasta, w której wówczas nie zdiagnozowano żadnych mocnych stron gospodarczych, po prawie 15 latach stwierdzenie, że negatywne procesy zachodzące w gospodarce Lublina zostały przezwyciężone, jest jak najbardziej zasadne. Nowoczesna infrastruktura drogowa i transport publiczny wewnątrz miasta, drogi dojazdowe, obwodnica oraz budowane drogi ekspresowe włączające Lublin w krajową sieć autostrad, dynamicznie rozwijający się Port Lotniczy Lublin S.A. oraz modernizowana szybka kolej do Warszawy, to tylko niektóre elementy ciągłego procesu umacniania pozycji konkurencyjnej Lublina w procesie stawania się metropolią w skali europejskiej (Sagan, 2018b, s. 127-128).

Dokonując porównania tempa przyrostu miejsc pracy z poziomem osiąganych przychodów przez przedsiębiorstwa przemysłowe, bez wątpienia można postawić tezę, że wzrost poziomu uprzemysłowienia dokonuje się przy wykorzystaniu nowoczesnych technologii obejmujących automatyzację i robotyzację produkcji. Tempo rozwoju technologii kształtujących procesy produkcji wymusza przyspieszenie wdrażania w zakładach przemysłowych technologii związanych z wykorzystaniem Internetu rzeczy (Internet of things) oraz systemów cyber-fizycznych. W chwili obecnej możemy zaobserwować koleją fazę złożonego procesu reindustrializacji gospodarki Lublina, budowanej na bazie rozwiązań związanych z automatyzacją i robotyzacją produkcji. Atrakcyjność Lublina jako miejsca lokowania i rozwoju przedsiębiorstw przemysłowych będzie bowiem ściśle związana z umiejętnością wykorzystania globalnych trendów $\mathrm{w}$ technologiach produkcji, między innymi poprzez zbudowanie środowiska 
współpracy odpowiadającego na coraz bardziej palące wyzwania gospodarki globalnej (Popik, 2018).

W świetle dotychczasowych przemian gospodarczych poprawa warunków rozwoju przedsiębiorstw przemysłowych oraz wdrażanie mechanizmów wsparcia dla wzrostu produkcji i zatrudnienia w przemyśle stanowią poważne wyzwania. Sukces rozwoju opartego na czynnikach endogenicznych w dużym stopniu zależy od podmiotów odpowiedzialnych za opracowanie i wdrażanie miejskich polityk. Proces reindustrializacji oraz neoindustrializacji miast poprzemysłowych może być determinowany poprzez tworzenie systemów produkcyjnych, które przybierając formę sieci wzajemnych relacji, łączą w sobie aspekty gospodarcze, społeczne oraz przestrzenne (Błaszczyk, 2015, s. 15). Wzrost produktywności, a tym samym zyskowności prowadzonej działalności gospodarczej może być m.in. efektem prowadzenia aktywnej polityki wspierania klastrów przemysłowych. Wychodząc naprzeciw rosnącym oczekiwaniom odnawiającego się przemysłu, opartego na zaawansowanych technologiach, oprócz polityki klastrowej konieczne staje się zdefiniowanie założeń szeroko rozumianej polityki budowania lokalnych systemów przemysłowych, wykorzystujących posiadane zasoby i przewagi konkurencyjne. Decydenci, zamiast podejmowania działań o charakterze bezpośredniej pomocy publicznej, powinni dążyć do rozwoju kapitału kreatywnego, zwiększenia dostępności wykwalifikowanych kadr i rozwiązań technologicznych. Umiejętnie prowadzona na wszystkich szczeblach zarządzania polityka przemysłowa bez wątpienia przyczyni się do poprawy struktury wytwarzania w przemyśle oraz wzmocni konkurencyjność przedsiębiorstw przemysłowych. Dla Lublina oznaczać to będzie większą konkurencyjność miasta i jego dochody, a także napływ nowych mieszkańców do aglomeracji lubelskiej.

\section{Bibliografia}

Błaszczyk, M. (2015). Uprzemysłowienie miasta postfordowskiego jako problem polityczny. Acta Universitatis Lodziensis. Folia Sociologica, 52, 5-25.

Cienkiera, P., \& Żyśko, R. (2017). Podstawowe informacje o sytuacji w sektorze przemysłu w Lublinie w latach 1989-2009. W: M. Sagan (red.), Podstrefa Lublin Specjalnej Strefy Ekonomicznej (2007-2017). W kierunku inteligentnej reindustrializacji miasta (ss. 14-25). Lublin, Polska: Wydawnictwo Episteme.

Gruba, P., Niewiadomski, I., \& Olchowska, P. (2017). Inwestorzy prowadzący działalność na terenie Podstrefy Lublin. W: M. Sagan (red.), Podstrefa Lublin Specjalnej Strefy Ekonomicznej (2007-2017). W kierunku inteligentnej reindustrializacji miasta (ss. 76-111). Lublin, Polska: Wydawnictwo Episteme. 
GUS (2019). Bank Danych Lokalnych. Pozyskano z https://bdl.stat.gov.pl/ (dostęp: 05.11.2019).

Karpiński, A., Paradysz, S., Soroka, P., \& Żółtkowski, W. (2013). Jak powstawały i jak upadały zakłady przemysłowe w Polsce. Warszawa, Polska: Muza S.A.

Kotyński, J. (2016). Rozwój gospodarczy Polski w drugiej dekadzie XXI wieku na tle zmian globalnych. Zeszyty Naukowe Akademii Finansów i Biznesu Vistula, 47(2), 7-18.

Krzysztofik, R., \& Szmytkie, R. (2018). Procesy depopulacji w Polsce w świetle zmian bazy ekonomicznej miast. Przeglad Geograficzny, 90, 309-329.

Pisano, G. P., \& Shih, W. C. (2009). Restoring American competitiveness. Harvard Business Review, 87(7-8), 114-125.

Popik, P. (2018). Park przemysłowy jako narzędzie reindustrializacji miasta. W: P. Maleszyk \& M. Sagan (red.), Lublin 2030: europejska metropolia? (ss. 185-210). Lublin, Polska: Wydawnictwo Urzędu Miasta Lublin.

Przygoda, M. (2013). Atrakcyjność inwestowania $w$ regionach słabo rozwiniętych. Warszawa, Polska: Wydawnictwo Naukowe Wydziału Zarządzania Uniwersytetu Warszawskiego.

Sagan, M. (2014). Lublin przemysłowy - strategia dla reindustrializacji miasta. W: M. Sagan \& K. Żuk (red.), Lublin 2020. Cztery oblicza przyszłości miasta (ss. 179-189). Lublin, Polska: Wydawnictwo UMCS.

Sagan, M. (2017a). Wprowadzenie. W: M. Sagan (red.), Podstrefa Lublin Specjalnej Strefy Ekonomicznej (2007-2017). W kierunku inteligentnej reindustrializacji miasta (ss. 9-11). Lublin, Polska: Wydawnictwo Episteme.

Sagan, M. (2017b). Znaczenie lubelskiej podstrefy ekonomicznej dla lokalnej gospodarki i procesów reindustrializacji miasta (2007-2017). W: M. Sagan (red.), Podstrefa Lublin Specjalnej Strefy Ekonomicznej (2007-2017). W kierunku inteligentnej reindustrializacji miasta (ss. 28-45). Lublin, Polska: Wydawnictwo Episteme.

Sagan, M. (2018a). Lublin 2030 - wyzwania rozwojowe. W: P. Maleszyk \& M. Sagan (red.), Lublin 2030: europejska metropolia? (ss. 17-32). Lublin, Polska: Wydawnictwo Urzędu Miasta Lublin.

Sagan, M. (2018b). Lublin gospodarczy po 1990 roku. W: Z. Pastuszak \& I. Skibińska-Fabrowska (red.), Lublin przedsiębiorczy. 700 lat historii, 200 lat doświadczeń (ss. 107-122). Lublin, Polska: Wydawnictwo UMCS.

Śliwa, R., \& Waląg, P. (2017). Industrializacja i deindustrializacja gospodarki. Przyczynek do dyskusji nad reindustrializacją gospodarki Polski. Nierówności Społeczne a Wzrost Gospodarczy, 52, 121-135.

Urząd Miasta Lublin (2019). Niepublikowane materiały Wydziału Strategii i Obsługi Inwestorów (2008-2018) oraz Wydziału Strategii i Przedsiębiorczości (2019). 
Urząd Statystyczny w Lublinie (2017). Historia Lublina w liczbach. Pozyskano z https:// lublin.stat.gov.pl/download/gfx/lublin/pl/defaultaktualnosci/76o/20/1/1/historia_lublina_w_liczbach_internet_publikacyjny3.pdf (dostęp: 05.11.2019).

\section{Streszczenie}

Zmiany zachodzące w sektorze przemysłu w Lublinie po 1989 r. można podzielić na kilka etapów. Transformacja ustrojowa, a przy tym przemiany polityczne i społeczno-ekonomiczne, zweryfikowały funkcjonowanie podmiotów gospodarczych. Po likwidacji dużych zakładów przemysłowych i związanych z tym masowych zwolnieniach Lublin, z miasta znanego z dobrze rozwiniętego przemysłu, stał się symbolem upadku sektora produkcji, czego przejawem był spadek liczby osób pracujących w przemyśle o 75\%. Lata 1994-1997 to warunkowany m.in. dobrą koniunkturą rozwój postaw przedsiębiorczych i poprawa sytuacji na rynku pracy. Jednak początek XXI wieku przyniósł kolejne dwie fazy spadkowe: opóźnioną, post-transformacyjną deindustrializację miasta w latach 1999-2002 i globalny kryzys finansowy i gospodarczy w 2008 r. Utworzenie Podstrefy Lublin Specjalnej Strefy Ekonomicznej, a przy tym świadomie i umiejętnie prowadzona od 2011 roku polityka gospodarcza, doprowadziły do niespotykanej dotąd dynamiki rozwoju gospodarczego miasta i kreacji wysoko rozwiniętego pod względem technologicznym przemysłu.

SŁOWA KLUCZOWE: przemysł, rozwój regionalny i lokalny, konkurencyjność przedsiębiorstw

\section{Summary}

The changes taking place in the industrial sector in Lublin after 1989 can be divided into several stages. The political transformation, as well as political and socio-economic changes, verified the functioning of economic entities. After the liquidation of large industrial plants and the associated mass layoffs, Lublin became a symbol of the collapse of the manufacturing sector, which was reflected in a 75\% drop in the number of people employed in the industry. The years 1994-1997 were the period of development of entrepreneurial mindsets and improvement of the situation on the labour market. However, the beginning of the 21st century brought another two inheritance phases: the delayed, post-transformation deindustrialisation of the city in 1999-2002 and the global financial and economic crisis in 2008. From that point on, Lublin started to record successes. Poland's accession to the European Union, the creation of the Lublin Subzone of the Special Economic Zone, and at the same time the conscious and skillful economic policy led to the unprecedented dynamics of the economic development of the city and the increasingly rapid development of highly developed manufacturing sector in terms of technology.

KEYWORDs: Manufacturing sector, local and regional development, the competitiveness of businesses 


\section{Nota o autorach}

Dr Mariusz Sagan - Szkoła Główna Handlowa w Warszawie, Kolegium Nauk o Przedsiębiorstwie, Instytut Rynków i Konkurencji, Zakład Strategii Konkurencji, Urząd Miasta Lublin, dziedziny działalności naukowej: rozwój regionalny i lokalny, zarządzanie międzynarodowe, ekonomia instytucjonalna; e-mail: mariusz.sagan@sgh.waw.pl; ORCID: oooo-0oo3-3454-691X.

Mgr Paulina Olchowska - Urząd Miasta Lublin, Fundacja Lubelska Wyżyna Motoryzacyjna i Maszynowa; główne dziedziny działalności naukowej: rozwój regionalny i lokalny, atrakcyjność inwestycyjna miast i regionów, przedsiębiorczość; e-mail: olchowska.paulina@gmail.com. 